\title{
Characterization of Resistance to Squash Silverleaf Disorder in Summer Squash
}

\author{
Kristen Young and Eileen A. Kabelka ${ }^{1}$ \\ University of Florida, Institute of Food and Agricultural Sciences, \\ Horticultural Sciences Department, 1301 Fifield Hall, P.O. Box 110690, \\ Gainesville, FL 32611-0690
}

Additional index words. breeding, cucurbits, Cucurbitaceae, disease resistance

\begin{abstract}
Feeding nymphs of the silverleaf whitefly, Bemisia argentifolii (formerly known as Bemisia tabaci Gennadius, B strain), cause a physiological disorder known as squash silverleaf (SSL) in summer squash (Cucurbita pepo L.). This disorder is characterized by a progressive silvering on the upper leaf surface caused by the development of large air spaces between the palisade mesophyll cells and the adaxial epidermis. Severely symptomatic plants can exhibit stunting and fruit yield reduction. A University of Florida $C$. pepo breeding line, designated Zuc76, confers resistance to this disorder and its inheritance was characterized. Data from $F_{1}, F_{2}$, and backcross progeny from crossing a SSL disorder-susceptible zucchini squash $(C$. pepo) with Zuc76 indicated resistance is conferred by a single recessive gene. Determining the mode of inheritance of SSL disorder resistance found in Zuc76 will contribute to future studies to develop SSL disorder-resistant $C$. pepo cultivars with superior horticultural potential.
\end{abstract}

Squash silverleaf (SSL) disorder is an economically important physiological disorder affecting squash (Cucurbita pepo L.) throughout the United States, the Caribbean region, and Israel (Cardoza et al., 1999). It is characterized by silvering of the veins and of the adaxial leaf surface caused by the progressive development of large air spaces between the palisade mesophyll cells and the adaxial epidermis attributable possibly to increased or prolonged cell wall degradation (Jimenez et al., 1995, Schmalstig and McAuslane, 2001). Silvered leaves exhibit reduced photosynthetic ability possibly as a result of a significant increase in chloroplast disruption and light reflectance (Schmalstig and McAuslane, 2001). Severely symptomatic plants can exhibit stunting and fruit yield reduction (Maynard and Cantliffe, 1989; Simons et al., 1988). In severe cases, the disorder may affect squash fruit, which appear blanched, rendering them unmarketable.

The symptoms of SSL disorder are induced by feeding immature nymphs of the silverleaf whitefly [Bemisia argentifolii (formerly known as Bemisia tabaci Gennadius, B strain)] (Costa et al., 1993; Schuster et al., 1991). Silvering symptoms are expressed on new leaves on maturation distal to the site of the nymph feeding (Jimenez et al., 1995; Schuster et al., 1991). When nymphs are removed, the older leaves where nymphs have fed remain silvered. New growth is free of symptoms (Jimenez et al., 1995). The

Received for publication 26 Mar. 2009. Accepted for publication 17 Apr. 2009.

${ }^{1}$ To whom reprint requests should be addressed; e-mailekabelka@ufl.edu. expression of symptoms is dependent on density of nymphs present, level of environmental stress, and cultivar (Paris et al., 1993).

Populations of silverleaf whitefly can be reduced through cultural and biological methods; however, control by chemical means is difficult as a result of the whitefly's resistance to some pesticides (McAuslane, 2007). Furthermore, the feeding nymphs and adults are found on the underside of leaves, which are difficult to reach with some types of insecticides. A source of resistance to SSL disorder within summer squash, designated Zuc76, was developed at the University of Florida. The objective of this project was to characterize the inheritance of resistance to SSL disorder within this summer squash breeding line.

\section{Materials and Methods}

Plant material. The SSL disorder-susceptible C. pepo cultivar, Black Beauty (BKB), and the SSL disorder-resistant C. pepo breeding line, Zuc76, were used as parents to establish segregating populations. 'Black Beauty' was obtained from commercial companies (Seed Savers, Decorah, IA; and Reimer Seeds, Mount Holly, NC). Controlled pollinations were carried out in the greenhouse to generate $\mathrm{F}_{1}(\mathrm{BKB} \times \mathrm{Zuc} 76), \mathrm{F}_{2}$, and backcross $\left(\mathrm{BKB} \times \mathrm{F}_{1}, \mathrm{~F}_{1} \times \mathrm{BKB}\right.$, and $\mathrm{F}_{1} \times$ Zuc76, respectively) progenies.

Greenhouse experimental design. Seed for all studies were sown in individual $15.2-\mathrm{cm}$ standard round plastic pots containing Fafard Growing Mix \#3S (Fafard Inc., Agawam, MA). Studies to evaluate the parents, $F_{1}, F_{2}$, and $\mathrm{BC}_{1}$ progeny were performed using $61-\mathrm{cm}^{3}$ cages covered with fine mesh cloth. Each cage contained six randomly chosen plants. Plants were watered once daily. As seedlings reached the first true-leaf stage, slow-release fertilizer (Osmocote, 14-14-14 N:P:K; Grace Sierra Horticulture Products, Milpitas, CA) was applied according to the manufacturer's directions. Temperature in the greenhouse was maintained between 25 to $35^{\circ} \mathrm{C}$ during the course of this experiment. Supplemental lighting was used, when needed, to maintain a 14-h daylength.

Whitefly culture and plant infestation. Whitefly adults were obtained from a colony reared on cotton (Gossypium hirsutum) and collard (Brassica oleracea) in a laboratory maintained at $22{ }^{\circ} \mathrm{C}$. Supplemental lighting was provided for a daylength of $14 \mathrm{~h}$. Plant infestation was performed using a modified procedure based on McAuslane et al. (2004). The number of aligned male-female whitefly pairs used in this study was based on tests performed by Cardoza et al. (1999) and McAuslane et al. (2004). Starting at the second to third true-leaf stage, plants were infested with 30 pairs of mixed-age adult whiteflies aspirated into vials as aligned malefemale pairs from the surface of a yellow foam card in the rearing cages. Whiteflies were released by placing opened vials under the leaf canopy of each plant. Continuous feeding and ovipositing by the whiteflies were allowed for the duration of the experiments. Parental and $F_{1}$ plants grown in noninfested cages served as negative controls.

Scoring for plant response to whitefly infestation and data analysis. Plants were visually rated for severity of SSL disorder symptoms $21 \mathrm{~d}$ after infestation. The most silvered leaves of each plant showing symptoms were scored using a scale of 0 (no silvering) to 5 (95\% to $100 \%$ silvering) (Paris et al., 1987). Plants rated as 0 were considered resistant to SSL disorder, whereas those rated 1 through 5 were considered susceptible. $\chi^{2}$ goodness of fit was used to test fit to the expected segregation ratios within segregating $\mathrm{F}_{2}$ and $\mathrm{BC}_{1}$ progeny to characterize resistance to SSL disorder.

\section{Results and Discussion}

Silvering of veins, interveinal areas, and/ or the entire abaxial leaf surface was found in plants susceptible to the SSL disorder $21 \mathrm{~d}$ after whitefly infestation (Table 1). These symptoms were absent in plants resistant to SSL disorder when grown in whiteflyinfested cages under the conditions of this study. Plants serving as negative controls remained free of symptoms. All experimental $F_{1}$ progeny exhibited symptoms similar to the SSL disorder-susceptible parent, 'Black Beauty', suggesting complete dominance of the allele associated with SSL disorder susceptibility. $F_{2}$ progeny segregated in a $1: 3$ [resistant (R):susceptible (S)] ratio. Progeny of the reciprocal backcrosses to the SSL disorder-susceptible parent were all susceptible. Progeny of the backcross to the SSL disorder-resistant parent segregated in a 1:1 $(\mathrm{R}: \mathrm{S})$ ratio. The segregation ratios support a model in which resistance to SSL disorder 
Table 1. Segregation for resistance to squash silverleaf (SSL) disorder caused by the silverleaf whitefly (Bemisia argentifolii) in 'Zuc76', 'Black Beauty', and their $\mathrm{F}_{1}, \mathrm{~F}_{2}$, and $\mathrm{BC}$ progeny.

\begin{tabular}{|c|c|c|c|c|}
\hline \multirow[b]{2}{*}{ Genotype } & \multicolumn{2}{|c|}{ No. of plants ${ }^{z}$} & \multirow[b]{2}{*}{ Expected ratios (R:S) } & \multirow[b]{2}{*}{$\chi^{2}$} \\
\hline & $\mathrm{R}$ & $\mathrm{S}$ & & \\
\hline Zuc76 (Z76) & 6 & 0 & - & - \\
\hline Black Beauty (BKB) & 0 & 24 & - & - \\
\hline $\mathrm{F}_{1}(\mathrm{BKB} \times \mathrm{Z76})$ & 0 & 26 & - & - \\
\hline $\mathrm{F}_{2}(\mathrm{BKB} \times \mathrm{Z76})$ & 51 & 128 & $1: 3$ & $1.16 \mathrm{NS}$ \\
\hline $\mathrm{BC}_{1}\left(\mathrm{~F}_{1} \times \mathrm{Z76}\right)$ & 35 & 45 & $1: 1$ & $1.25 \mathrm{NS}$ \\
\hline $\mathrm{BC}_{1}\left(\mathrm{BKB} \times \mathrm{F}_{1}\right)$ & 0 & 56 & $0: 1$ & - \\
\hline $\mathrm{BC}_{1}\left(\mathrm{~F}_{1} \times \mathrm{BKB}\right)$ & 0 & 23 & $0: 1$ & - \\
\hline
\end{tabular}

${ }^{\mathrm{z}} \mathrm{R}=\mathrm{SSL}$ disorder-resistant; $\mathrm{S}=\mathrm{SSL}$ disorder-susceptible.

Ns, $\chi^{2}$ value not significantly different at $P \leq 0.05$.

in Zuc76 is conferred by a single recessive gene.

Squash silverleaf disorder resistance in a related species, C. moschata, was also found to be conferred by a single recessive gene $(s l)$ (Wessel-Beaver, 2000), but it is unknown if the gene is allelic to that found in C. pepo. In a earlier study to determine the inheritance of the resistance to SSL disorder found within the $C$. pepo Zuc76 breeding line, Carle et al. (1998) established that inheritance of the SSL disorder resistance was recessive but were inconclusive in the number of genes involved, proposing one, two, or four. The method for screening involved shaking whiteflies from host plants onto the squash plants, which resulted in varied levels of the plants' exposure to the whiteflies. Because infestation density of whitely nymphs is directly correlated to the level of expression of SSL disorder symptoms (Costa et al., 1993; Schuster et al., 1991; Yokomi et al., 1990), distributing a known number of adult mating pairs of whiteflies to each plant during the current study ensured consistent levels of exposure. The environment is also known to affect the expression of SSL symptoms. Paris et al. (1993) found drought stress increased the severity of silvering symptoms in $C$. pepo cultivars under controlled greenhouse conditions. Photoperiod and temperature may also contribute to differential symptom expression (Cardoza et al., 1999).
An increase in temperature affects whiteflies by shortening their developmental time, including the time to emergence of the feeding nymphs (Butler et al., 1983; Cardoza et al., 1999). Conducting the inheritance study under controlled greenhouse conditions limited the effects of temperature, photoperiod, and moisture level on symptom expression.

Identifying the mode of inheritance of SSL disorder resistance found in Zuc76 will contribute to future studies to develop a SSL disorder-resistant $C$. pepo cultivar with superior horticultural potential. Molecular analysis of the segregating progeny developed in this study is currently underway to identify markers linked to SSL. Codominant polymerase chain reaction-based molecular markers tightly linked (less than $5 \mathrm{cM}$ ) to SSL would provide the most benefit allowing distinction between individuals that are homozygous or heterozygous at this loci.

\section{Literature Cited}

Butler, G.D., T.J. Henneberry, and T.E. Clayton. 1983. Bemisia tabaci (Homoptera: Aleyrodidae): Development, oviposition, and longevity in relation to temperature. Ann. Entomol. Soc. Amer. 76:310-313.

Cardoza, Y.J., H.J. McAuslane, and S.E. Webb. 1999. Mechanisms of resistance to whiteflyinduced squash silverleaf disorder in zucchini. J. Econ. Entomol. 92:700-707.

Carle, R.B., S. Webb, and C. Chandler. 1998. Genetic analysis of resistance to whitefly sil- vering in Cucurbita pepo L., p. 84-89. In: McCreight, J.D. (ed.). Cucurbitaceae '98: Evaluation and enhancement of cucurbit germplasm. ASHS, Alexandria, VA.

Costa, H.S., D.E. Ullman, M.W. Johnson, and B.W. Tabashnik. 1993. Squash silverleaf symptoms induced by immature, but not adult, Bemisia tabaci in Arizona. Phytopath. 83:763-766.

Jimenez, D.R., R.K. Yokomi, R.T. Mayer, and J.P. Shapiro. 1995. Cytology and physiology of silverleaf whitefly-induced squash silverleaf. Physiol. Mol. Plant Pathol. 46:227-242.

Maynard, D.N. and D.J. Cantliffe. 1989. Squash silverleaf and tomato irregular ripening: New vegetable disorders in Florida. Veg. Crop Fact Sheet, Florida Cooperative Extension Service, IFAS, UF.

McAuslane, H.J. 2007. Sweetpotato whitefly B biotype of silverleaf whitefly, Bemisia tabaci (Gennadius) or Bemisia argentifolii Bellows and Perring (Insecta: Hemiptera: Aleyrodidae). 25 Mar. 2009. <http://edis.ifas.ufl.edu/pdffiles/ IN/IN28600.pdf>.

McAuslane, H.J., J. Chen, R.B. Carle, and J. Schmalstig. 2004. Influence of Bemisia argentifolii (Homoptera: Aleyrodidae) infestation and squash silverleaf disorder on zucchini seedling growth. J. Econ. Entomol. 97:1-11.

Paris, H.S., H. Nerson, and Y. Burger. 1987. Leaf silvering of Cucurbita. Can. J. Plant Sci. 67:593-598

Paris, H.S., P.J. Stoffella, and C.A. Powell. 1993. Susceptibility to leaf silvering in the cultivar groups of summer squash. Euphytica 69:69-72.

Schmalstig, J.G. and H.J. McAuslane. 2001. Developmental anatomy of zucchini leaves with squash silverleaf disorder caused by the silverleaf whitefly. J. Amer. Soc. Hort. Sci. 126:544554.

Schuster, D.J., J.B. Kring, and J.F. Price. 1991. Association of the sweetpotato whitefly with a silverleaf disorder of squash. HortScience 26:155-156.

Simons, J.N., P.J. Stofella, K.D. Shuler, and R.N. Raid. 1988. Siilver-leaf of squash in south Florida. Proc. Fla. State Hort. Soc. 101:397-399.

Wessel-Beaver, L. 2000. Inheritance of silverleaf resistance in Cucurbita moschata. Proc. Cucurbitaceae 2000. Acta Hort. 510:289-295.

Yokomi, R.K., K.A. Hoelmer, and L.S. Osborne. 1990. Relationship between the sweetpotato whitefly and the squash silverleaf disorder. Phytopath. 80:895-900. 